\title{
Faith-Based Public Foundations: Identifying the Field and Assessing its Impact
}

\author{
Accepted for publication in The Foundation Review
}

\author{
Allison K. Ralph, Ph.D. \\ The Aspen Institute \\ Allison.Ralph@aspeninstitute.org \\ Brad R. Fulton, Ph.D. \\ Indiana University \\ fulton@indiana.edu \\ Samuel Allen \\ Hobart and William Smith Colleges \\ sallen@hws.edu
}

\begin{abstract}
Charitable activity is a core tenet of most faith traditions, and many charitable organizations have a religious identity. However, little is known about the prevalence and scale of faith-based foundations, and how they differ from secular foundations. This study identifies the field of public foundations, differentiates between faith-based and secular foundations, and compares their characteristics by analyzing Form 990 data. Our analysis estimates that $24 \%$ of all public charities operate as foundations and that $17 \%$ of public foundations are faith-based. We use these findings to generate first-ever estimates for the entire field of public foundations. Based on our analysis and calculations using nonprofit sector data, there are approximately 300,000 public foundations in the U.S., and we estimate that 52,000 of them are faith-based. Collectively, these faith-based public foundations have at least $\$ 90$ billion in assets, and in 2015, they contributed at least $\$ 8$ billion to charitable causes. Additional analyses comparing faith-based and secular foundations indicate that faith-based foundations tend to be older, have greater revenue and more assets, receive less money from the government, and distribute more money in grants, especially to international causes. This study provides an important lens through which to examine the field of public foundations and better understand similarities and differences among faith-based and secular foundations. It can help scholars analyze relationships between religion and philanthropy, help grantmakers assess foundations through a faith-based-secular grid, and help grantees identify funders who share a similar orientation toward religion. Overall, this study reveals the meaningful presence of faith-based foundations, indicates the scale of their impact, and underscores religion's enduring and significant influence in the philanthropic sector.
\end{abstract}

Keywords: public charities, foundations, grantees, faith-based, religion, secular 


\section{Faith-Based Public Foundations: Identifying the Field and Assessing its Impact}

\section{Introduction}

The American philanthropic landscape shapes, and is shaped by, broad cultural, religious, political, and governmental trends. Philanthropic organizations and individuals have been among the most influential players in the development of these trends (Hall, 2000; Soskis, 2020; Zunz, 2012), driving change with intentional (and sometimes with unintentional) consequences in tax policies, social movements such as progressivism, political alliances, and jurisprudence (via litigation, but also by supporting law schools and think tanks that train lawyers and judges and develop new policy positions). Underlying much of this activity for a substantial subset of the philanthropic field are faith values rooted in religious traditions, institutions, and communities (Fulton \& Wood, 2018).

American philanthropic and charitable traditions are undergirded by faith values - personal or corporate principles or standards of behavior that are derived from religious texts, traditions, or group norms (Mundey et al., 2019). Many of America’s largest foundations_-organizations whose primary activity is to raise and distribute funds for charitable purposes - were founded in response to a religiously based concern for the well-being of American society (Davis, 2013; Jungclaus, 2021; Sievers, 2010; Yeager, 1990). Much of the Progressive movement of the early 20th century was populated, advanced, and underwritten by people of faith as a moral response to increasing corporate and political corruption. That movement included the establishment of professional philanthropic organizations (Cook and Halpin, 2010; Yeager, 1990). Religious and political conservatives also conscientiously built-up their own philanthropic foundation and grantee landscape in the 1970s and 80s (Zunz, 2012). Over time, both progressive and conservative religious organizations formed coalitions to lobby Congress and wield influence in 
U.S. tax policy to shape the nonprofit sector (Zunz, 2012: 248-55). As a result, much of the current nonprofit landscape was shaped by faith-based philanthropic organizations.

However, during the same period from the early $20^{\text {th }}$ to early $21^{\text {st }}$ century, a wave of secularization swept over the philanthropic, political, and cultural establishments. Increasingly, many foundations minimized the religious aspects of their origins. At the same time, they emphasized professionalized staff, research, and efficiency (Bremner, 1988). The story of this pivot has been told in detail for philanthropies like the Rockefeller Foundation, Danforth Foundation, and the Pew Charitable Trusts (Jungclaus, 2021; Lindsay \& Wuthnow, 2010; Zunz, 2012). These histories highlight a wider trend in American culture that connected "secular" with "professional" and "scientific," while connecting "faith-based" with "unprofessional" and "antiscientific" (Varo, 2016). ${ }^{1}$ By the late $20^{\text {th }}$ century, Peter Dobkin Hall, an eminent scholar of nonprofit history, characterized the feeling between organized philanthropy and organized religion as "a mutual wariness" (Hall, 1992). Hall shared this perspective nearly three decades ago, before the rise of the religious "nones" (i.e., people with no religious affiliation) and other signs of widespread cultural secularization in the $21^{\text {st }}$ century (Gallup, 2019). While some scholars may define secular as being in opposition to religion, our use of the term secular, in reference to a person, organization, or activity, means to be non-religious. ${ }^{2}$ Religion itself is a way of behaving, a set of beliefs, a community of belonging, or some combination of all three,

\footnotetext{
${ }^{1}$ Studies in cognitive linguistics show that groups of associations and their opposites are collated into sets of meaning by members of a particular community over time (Varo, 2016). These associations can "carry over" meanings to each other and to their perceived opposites. (Lakoff \& Johnson, 1980). In this case, we suggest that negative connotations about religion, such as lack of professionalism, are carried over by the association between "secular" and "professional."

${ }^{2}$ The terms secular, religious, and religion are complex concepts with dozens of different contextually-dependent meanings on which the literature is expansive. Our definitions pertain only to our use of them in this paper. Additional literature on secularization is vast. One might start with Jürgen Habermas and Joseph Ratzinger's Dialectics and Charles Taylor's A Secular Age (Ratzinger \& Habermas, 2006; Taylor, 2009).
} 
often rooted in specific oral traditions or written texts, and "religious" describes a person, organization, or activity associated with a particular tradition.

Another marker of the secularization of philanthropy has been the steep decline in foundations' giving to nonprofits focused on promoting religion over the last four decades (Eckhart Queenan et al., 2021; Inclusive America Project et al., 2020; Lindsay \& Wuthnow, 2010). Some faith-based charities and secular charities report difficulties partnering with each other because of underlying issues of mistrust (Eckhart Queenan et al., 2021; Ralph, 2021). These difficulties in partnering cause some faith-based organizations to minimize or disclaim their faith identity, not out of an interest in secularizing, but due to pragmatic fundraising needs (Markofski et al., 2019; Staton Bullard, 2021).

Other studies have claimed that funders "leave impact on the table" by avoiding faithbased organizations, doing disservice to their own strategic goals (Eckhart Queenan et al., 2021; Fulton, 2017). Recent studies have shown that faith values and religious communities are still substantial sources of charitable work. Faith-based nonprofit organizations comprise a significant portion (approximately $40 \%$ ) of the nonprofit landscape, which includes 384,000 religious congregations (Brauer, 2017), 110,0000 other "religion-related" organizations (NTEE X), and the 181,000 religiously identified organizations doing "secular" work (e.g., prison reentry programs, food banks, hospitals, art programs) (Fulton, 2020). Further, compared to secular counterparts, these organizations tend to be older, have more volunteers, generate more revenue, and receive more donations (Ressler et al., 2020). The finding that faith-based organizations are frequently better equipped than their secular counterparts belies any perception that faith-based nonprofits are unprofessional.

While Ressler and his colleagues (2020) identified faith-based grantees participating in "secular" charitable work, little is known about the current field of faith-based grantmaking 
organizations. ${ }^{3}$ This study helps to fill that gap by identifying the field of public foundations, differentiating between faith-based and secular foundations, and comparing their characteristics. We define a public foundation as an organization that files a Form 990 tax return and whose primary activity is to raise and distribute funds for charitable purposes. This study provides the first-ever estimate for the total number of public foundations in the U.S. as well as the percentage of those that identify as faith-based. Based on our analysis and calculations using nonprofit sector data, there are approximately 300,000 public foundations in the U.S. We estimate that $17 \%$ of those foundations are faith-based, they have at least $\$ 90$ billion in assets, and in 2015 , they contributed at least $\$ 8$ billion to charitable causes.

This study expands understanding of institutional philanthropy by identifying the prevalence and scale of faith-based public foundations. It also reveals how they differ from secular foundations. For example, our analysis indicates that faith-based foundations tend to be older, generate a greater annual revenue, and have more assets, suggesting that faith-based foundations are more established than secular foundations. We also observe that faith-based foundations are less likely to receive funding from the government and they are more likely to fund international charitable causes, suggesting that their goals, priorities, and values differ from secular foundations as well. At the same time, we find that faith-based and secular foundations share similar operational approaches to philanthropy with regard to overhead expenses and administrative policies.

The philanthropic field can benefit from understanding the contingent of faith-based foundations for three reasons. First, those seeking to understand the field as a whole may find

\footnotetext{
${ }^{3}$ Ressler and his colleagues (2020) found that among all nonprofits engaged in non-religion-focused work, $15 \%$ have a religious identity and that their outcomes differ significantly from nonprofits that have a secular identity. Their study highlights the substantial scope and scale of faith-based nonprofits (i.e., organizations whose primary activity is something other than promoting religion) and the significant contributions they make to charitable activity.
} 
that faith-based foundations have different interests when seeking to shape cultural, political, and government trends. Second, for secular foundations seeking to begin or improve relationships with faith-based grantees, program officers at faith-based foundations may be able to assist in navigating those relationships. Third, faith-based foundations should know that a sizable contingent of other faith-based foundations exist, whose staff may face challenges unique to their position as faith-based in a field commonly understood to be secular.

\section{Data and Analysis}

To identify public foundations, differentiate between faith-based and secular foundations, and compare their characteristics, this study analyzes Form 990 data. Although any tax-exempt organization may file a Form 990, organizations with a total annual revenue that exceeds \$200,000 must file a Form 990. ${ }^{4}$ Form 990s contain detailed data on nonprofits, including information on their age, employees, revenue, expenses, mission, and internal policies (IRS, 2020). In 2016, the IRS made electronically-filed Form 990 data publicly available in a machinereadable format. It released 1.3 million Form 990s through Amazon Web Services for all e-filing nonprofit organizations (approximately 65\% of all 990 filers), covering 2011 to 2015 (AWS Public Sector Blog Team, 2016). ${ }^{5}$

Our analysis includes every 501(c)3 organization that e-filed a Form 990 for the 2015 tax year and whose form contains plausible values for the organizational characteristics of interest

\footnotetext{
${ }^{4}$ All religious congregations, regardless of the annual revenue, are exempt from having to file a Form 990.

${ }^{5}$ For a comprehensive review of the Form 990 data quality and limitations see Lampkin and Boris (2002) and Ely, Calabrese, and Jung (2021).
} 
( $\mathrm{N}=175,093)$; we removed cases with missing, negative, or implausible values. ${ }^{6} \mathrm{We}$ supplement the Form 990 data with information about the organizations from the IRS's Business Master File.

\section{Identifying Public Foundations}

The field of public charities includes organizations that make charitable contributions (foundations) and organizations that use those contributions to advance charitable causes (grantees). For example, the Silicon Valley Community Foundation (EIN 20-5205488) distributes funds to several grantees (e.g., Community Clinic Consortium - EIN 20-0782029, Immigrant Legal Resource Center - EIN 94-2939540, and Peninsula Family Services - EIN 94-1186169) that address needs consistent with the foundation's mission. Although foundations and grantees engage in distinct charitable activities (i.e., distributing funds and providing services), the IRS does not differentiate between them. It considers both to be public charities and requires them to file the same Form $990 .^{7}$ In our example, both the Silicon Valley Community Foundation and the Community Clinic Consortium are public charities and file the same Form 990. When registering nonprofit organizations, the IRS uses the National Taxonomy of Exempt Entities (NTEE) to differentiate organizations based on their primary tax-exempt activity. One of the categories is “grantmaking foundations" (NTEE T); however, a substantial number of nonprofits not coded as NTEE T organizations engage in grantmaking activity. Thus, up until now, the total number of public foundations in the U.S. has not been known. ${ }^{8}$

Our Form 990 dataset contains 7,704 NTEE T organizations, indicating that the IRS has coded approximately 4.4 percent of public charities as foundations. To check if there were, in fact,

\footnotetext{
${ }^{6}$ Analyses comparing e-filer data with the Business Master File that contains data on all registered nonprofits suggests that organizations that e-file are older and larger than organizations that do not e-file. Similar differences are observed when comparing organizations that file a Form 990 to organizations that are not required to file a Form 990 (IRS 2020 ). 7 The IRS distinguishes between public and private foundations, where the latter are required to file the Form $990 \mathrm{PF}$ rather than the Form 990. Our analysis does not include private foundations.

${ }^{8}$ We define public foundations as public charities (i.e., organizations that file a Form 990) and whose primary activity is to raise and distribute funds for charitable purposes.
} 
foundations among the non-NTEE T organizations in the dataset, we conducted the following analyses. First, we searched the organizations' names and coded as a foundation any organization whose name included one of the following terms: foundation, charitable trust, endowment, memorial fund, charities, friends of, and booster. Second, we searched the organizations' mission statements and flagged any organization whose statement included one of the following terms: charitable trust, foundation, endowment, and fund. Finally, we reviewed flagged cases to determine whether the organization met the following definition for being a foundation: "an organization whose primary activity is to raise and distribute funds for charitable purposes." If the organization met the definition, we coded it as a foundation. ${ }^{9}$

Through this process, we identified 33,627 additional foundations, bringing the total number of foundations in the dataset to 41,331 (24\%). Based on this analysis and calculations using data on the entire nonprofit sector, which includes nonprofits that do not e-file, there are approximately 300,000 public foundations in the U.S. ${ }^{10}$ However, because some foundations have not distributed funds for charitable purposes for several years, we restricted our analysis to only "active" foundations - foundations that have distributed at least one grant in the previous five years. In our dataset, 25,027 of the foundations meet this condition.

\section{Identifying Faith-Based Foundations}

After identifying the subset of active foundations, to differentiate between secular and faith-based foundations, we examined how those organizations described themselves in their name and mission statement. According to Chaves (2002:1537), "the most straightforward operationalization of an organization's religiousness probably is that it self-identifies as such by

\footnotetext{
${ }^{9}$ No congregations met these conditions; however, stand-alone congregational foundations (e.g. the First United Methodist Church of Waco Foundation, EIN: 74-2410127) that met these conditions were coded as foundations. ${ }^{10}$ Data retrieved from GuideStar.org on 9/7/2021 indicate that there are approximately 1.3 million 501c3 organizations in the U.S. These supplemental data and calculations are available upon request.
} 
having a religious marker in its formal name ... and/or religious language in its formal mission statement." Most scholars agree on the general boundary demarcating secular and faith-based organizations: secular organizations have no explicit identification with religion, while faithbased organizations do (Bielefeld \& Cleveland, 2013). Consequently, we searched the organizations' name and mission statement, as reported on their Form 990, for religious identity markers.

To do so, we used a dictionary compiled by Ressler and colleagues (2020) that contains 935 religious terms. If a foundation's name or mission statement contains any term in the dictionary, we coded it as faith-based. ${ }^{11} \mathrm{We}$ also followed the steps prescribed by Ressler and colleagues (2020) to identify potential "false positive" indicators (i.e., religious terms that might not indicate a religious identity in particular contexts). For example, instances where the term "saint" refers to the name of the city in which the foundation is located (e.g., Saint Paul, MN) rather than the name of a religious saint after whom the organization is named. Among the 25,027 active foundations we analyzed, we identified 4,333 (17\%) as faith-based, and in 2015, those foundations contributed at least $\$ 8$ billion to charitable causes. ${ }^{12}$

Although every foundation we coded as "faith-based" indicated a religious identity, these organizations vary widely in their level of religiosity. For example, some foundations are deeply shaped by faith values and limit their staff, population served, and/or activities according to religious principles. Whereas others were founded by faith inspiration, but are no longer guided by religious principles in their day-to-day operation (Goldsmith et al., 2006). A foundation's religiosity may influence its mission statement; sources of funding and affiliations with specific

\footnotetext{
${ }^{11}$ We also coded any foundation categorized as an NTEE X (religion-related) organization as "faith-based," regardless of whether its name or mission statement contains a religious term.

12 The total contribution amount is based on data only from e-filers. It does not include contributions made by faithbased foundations that filed by mail.
} 
religious traditions; the religious commitments of its board, staff, and volunteers; and the amount of religious referencing in its facilities, materials, funding priorities, and goals (Fulton, 2020).

\section{Comparing Faith-Based and Secular Foundations}

After differentiating between faith-based and secular foundations, we compared their characteristics. Prior research and theories related to religion and philanthropy suggest that the following organizational characteristics could be impacted by having a religious identity: age of foundation, number of employees, total revenue and sources of revenue, assets, fundraising expenses, amount given in grants and the geographic location of the grantees. ${ }^{13}$ Age of foundation: many of the first charities established in the U.S. had religious affiliations (Hall, 2006) Thus, we expected the average age of faith-based foundations to be greater than that of secular foundations. Number of employees: because religious people tend to volunteer more than nonreligious people (Lim \& MacGregor, 2012), we expected the average number of employees to be lower for faith-based foundations than secular foundations. Total annual revenue and assets: similarly, because religious households tend to give more money to charities than secular households (Bekkers \& Wiepking, 2011; Osili et al., 2021), we expected faith-based foundations to have greater average annual revenue and assets than secular foundations. Received no funding from the government and amount of revenue from non-government sources: given the separation of church and state and the challenges associated with the government funding faith-based organizations (Kennedy \& Bielefeld, 2002), we expected faith-based foundations to be more likely to receive no funding from the government and to generate a greater amount of revenue from non-government sources. Total amount given in grants: if faith-based foundations have more revenue and assets than secular foundations, we would expect them to distribute more

\footnotetext{
13 The scope of characteristics we can analyze is constrained by the data available on Form 990 s.
} 
money in grants. Amount given to foreign grantees: given religious people's predilection for giving to international aid (Schnable, 2015; Austin et al., 2022; Gazley et al., 2022), we expected faith-based foundations, compared to secular foundations, to distribute more grant funds to foreign grantees.

Our analysis also included the following organizational characteristics commonly examined in philanthropic research and where religious identity may be influential: proportion spent on administrative expenses (the ratio of administrative expenses to total expenses), amount spent on fundraising, and whether the organization has a conflict of interest policy, whistleblower policy, or document retention policy.

To reduce the influence of extremely large values and maintain easy interpretation of the results, we winsorized the top $1 \%$ of the values for the following characteristics: number of employees, total annual revenue, amount of revenue from non-government sources, total assets, total annual expenses, amount spent on fundraising, total amount given in grants, amount given to domestic grantees, and amount given to foreign grantees (Ghosh \& Vogt, 2012). Analysis performed on the non-winsorized sample produced similar results. Our analysis uses T-tests to examine whether the mean values for the faith-based foundation characteristics differ significantly from the mean values for the secular foundations.

Table 1 displays the mean values for all the active foundations for each of the characteristics discussed above as well as the mean values for the subsets of faith-based and secular foundations and the t-test results. The results indicate that compared to secular foundations, faith-based foundations tend to be older, generate more revenue, and have more assets. Meanwhile, faithbased foundations are less likely to receive money from the government; however, among foundations that receive government funding, faith-based foundations tend to receive more than secular foundations. In addition, although faith-based foundations are more likely to have no 
employees, among foundations that have any employees, faith-based foundations tend to have more employees than secular foundations. At the same time, the proportion of total expenses faith-based and secular foundations spend on administrative costs do not differ significantly. Faith-based and secular foundations show no difference in whether they have a conflict-ofinterest policy, whistleblower policy, or document retention policy. Finally, while faith-based foundations tend to have greater total expenses and spend more money on fundraising, they also tend to distribute more money in grants and are more likely to give to foreign grantees.

\section{Discussion}

Our findings illuminate the prevalence and scale of public faith-based funders across the philanthropic landscape, showing a substantial contingent of faith-based public foundations (approximately 52,000 total |32,000 active | 17\%). These findings indicate that faith-based foundations comprise a meaningful segment of the nonprofit sector and that they that differ from their secular counterparts along several important dimensions. Faith-based foundations tend to be older, generate a greater annual revenue, and have more assets than secular foundations, which suggests that many are well-established entities and operate with a high level of professionalism. Additionally, the analysis indicates that faith-based and secular foundations share similar administrative standards, which suggests that they learn could from exchanging ideas and best practices with each other.

As we laid out in the introduction, the wave of secularization over the last century led to a generalized cultural association, which is especially strong in the field of philanthropy, of “secular" with "professional," and "faith-based" with "unprofessional." Nevertheless, the perceived disconnect between professionalism and religion has led some faith-based foundations to minimize their own religious identity and made some secular foundations uneasy about working with faith-based organizations (Ralph, 2021). This disconnect can result in substantially 
reduced giving to faith-based organizations, even when those grantees are the best candidates to complete the work that foundations want to do, and in mistrust between secular and faith-based organizations (Fulton, 2020; Ressler et al., 2020; Townes et al., 2012). ${ }^{14}$ Other studies have already shown this avoidance to be harmful to foundations, grantees, and populations served (Eckhar Queenan et al., 2021). If the tendency to avoid faith-based organizations is, even in part, due to a widespread assumption that philanthropy is "secular," the existence of a substantial number of high-performing faith-based foundations may impact the field's practice of distancing itself from faith-based grantees.

Additionally, understanding the enduring relationships between religion and philanthropy, and between religion and the society philanthropy aims to improve, can help secular foundations increase their effectiveness and impact. Religion continues to be influential in public life, democratic engagement, and social and cultural movements in the U.S. and around the world (Fulton \& Wood, 2018). Further, shifting demographic trends in the U.S. show religious diversity increasing and the percentage of adherents to non-Christian faiths rising (Cox, 2020; Fulton \& Wood, 2017). Given this increasing religious diversity, understanding the role of religion and religious values in defining and shaping the "common good," along with the political and cultural implications of these diverse conceptions, is critical to sustaining a pluralistic democracy (Wood \& Fulton, 2015). To better support highly religious populations, staff at secular foundations could learn to partner effectively with the faith-based nonprofits that serve those populations.

\footnotetext{
${ }^{14}$ In 2019, when the Inclusive America Project at the Aspen Institute surveyed funders known to have previously funded faith-based grantees, one responded, "we don't fund that." This respondent failed to recognize where faith already existed in their portfolio. That kind of recognition failure can have devastating impacts on organizations at the receiving end of funder dollars.
} 
Faith-Based Public Foundations

More generally, funders across the board would do well to increase their adaptive capacity to meet the unique funding challenges of this particularly fraught cultural and political era (Allan \& DuPree, 2018). One source of information about navigating these challenges lies in the sizable contingent of faith-based foundations that we identify. Previous research has also identified "philanthropy-consulting partnerships" as a strategy to alleviate initial hesitancy or uncertainty between foundations and grantees with nuanced or complex identities and missions (Irie et al., 2015). Finally, avoiding the topic of religion in the philanthropic sector prevents a full understanding of it. The ebb and flow of social movements, such as secularization and the rise of politicized religion, will continue to impact future rounds of tax policy-making that broadly affect the philanthropic community.

\section{Future Research}

Along with helping to explore how religion and faith-based foundations shape the philanthropic field, our research uncovering the prevalence and scale of faith-based foundations in the U.S. lays the groundwork for future research in several areas. Now that the field is identified, researchers can investigate the types of issues and organizations these grantmakers support by reviewing their lists of publicly reported grantees. For example, they could assess whether faith-based foundations give exclusively to faith-based nonprofits, and whether secular foundations exclude faith-based nonprofits as potential grantees. This study can help scholars analyze relationships between religion and philanthropy, help grantmakers assess foundations through a faith-based-secular grid, and help grantees identify funders who share a similar orientation toward religion. Future studies can identify the field of private foundations, differentiate between faith-based and secular private foundations, and compare their characteristics. Additional extensions of this research include performing qualitative research on the self-identification of faith-based or secular organizations as compared with their identification here, investigating 
Faith-Based Public Foundations

other types of organizational identities (e.g., based on political orientation, demographic composition, etc.), and analyzing how a foundation's identity shapes its organizational and grantmaking practices. For example, future research could explore correlations between a foundation's identity and the identity of its grantees.

\section{Conclusion}

This study identifies the field of public foundations (beyond just NTEE T organizations) and provides an important lens through which to examine this field and better understand similarities and differences among faith-based and secular foundations. Not only do faith-based foundations appear to be more established than secular foundations, they comprise a meaningful segment of the field. We identify $17 \%$ of public foundations as faith-based and show that compared to secular foundations, faith-based foundations tend to be older, generate more revenue, and have more assets. In 2015 alone, these foundations contributed at least $\$ 8$ billion to their causes. Our analysis also indicates that faith-based foundations are less likely to receive money from the government but that, among foundations that receive government funding, faithbased foundations tend to receive more than secular foundations. In addition, although faithbased foundations are more likely to have no employees, among foundations that have any employees, faith-based foundations tend to have more employees than secular foundations. While faith-based foundations tend to have greater total expenses and spend more money on fundraising, they also tend to distribute more money in grants and are more likely to give to foreign grantees. Regarding common measures of professionalism, faith-based and secular foundations show no significant differences. Specifically, both types of organizations are equally likely to have conflict of interest, whistleblower, and document retention policies, and they allocate approximately the same proportion of their expenses to administrative costs. Overall, 
Faith-Based Public Foundations

this study reveals the meaningful presence of faith-based foundations, indicates the scale of their impact, and underscores religion's enduring and significant influence in the philanthropic sector. 


\section{References}

Allan, C., \& DuPree, A. S. (2018). Resilient Funders: How Funders Are Adapting to the Closing Space for Civil Society. The Foundation Review, 10(2), 93-105.

Austin, T. S., King, D. P., Bergdoll, J., \& Fulton, B. R. (2022). Defining and Estimating the Scope of U.S. Faith-Based International Humanitarian Aid Organizations. Voluntas (forthcoming).

AWS Public Sector Blog Team. (2016). IRS 990 Filing Data Now Available as an AWS Public Data Set. AWS Public Sector Blog. https://aws.amazon.com/blogs/publicsector/irs-990filing-data-now-available-as-an-aws-public-data-set/

Bekkers, R., \& Wiepking, P. (2011). Who gives? A literature review of predictors of charitable giving Part One: Religion, education, age and socialisation. Voluntary Sector Review, 2(3), 337-365.

Bielefeld, W., \& Cleveland, W. S. (2013). Defining Faith-Based Organizations and Understanding Them Through Research. Nonprofit and Voluntary Sector Quarterly, $42(3), 442-467$.

Brauer, S. G. (2017). How Many Congregations Are There? Updating a Survey-Based Estimate. Journal for the Scientific Study of Religion, 56(2), 438-448.

Bremner, R. H. (1988). American Philanthropy (2nd ed.). University of Chicago Press.

Chaves, M. (2002). "Religious organizations: Data resources and research opportunities." American Behavioral Scientist 45(10),1523-1549.

Cook, M., \& Halpin, J. (2010). The Role of Faith in the Progressive Movement. Center for American Progress.

Cox, D. A. (2020). Religious diversity and change in American social networks: How our social connections shape religious beliefs and behavior. The Survey Center on American Life. 
Davis, T. J. (Ed.). (2013). Religion in Philanthropic Organizations: Family, Friend, or Foe? Indiana University Press.

Eckhart Queenan, J., Grunert, P., \& Murphy, D. (2021). Elevating the Role of Faith-Inspired Impact in the Social Sector. The Bridgespan Group.

Ely, T. L., Calabrese, T. D. \& Jung, J. (2021). "Research implications of electronic filing of nonprofit information: Lessons from the United States' Internal Revenue Service Form 990 series." Voluntas published online ahead of print.

Fulton, B. R. (2017). Fostering Muslim Civic Engagement through Faith-Based Community Organizing. Journal of Muslim Philanthropy and Civil Society, 1(1), 23-39.

Fulton, B. R. (2020). Religious Organizations: Crosscutting the Nonprofit Sector. In W. W. Powell \& P. Bromley (Eds.), The Nonprofit Sector: A Research Handbook (3rd ed., pp. 579-597). Stanford University Press.

Fulton, B. R., \& Wood, R. L. (2017). Achieving and Leveraging Diversity through Faith-Based Organizing. In R. Braunstein, T. N. Fuist, \& R. H. Williams (Eds.), Religion and Progressive Activism (pp. 29-55). New York University Press.

Fulton, B. R., \& Wood, R. L. (2018). Civil Society Organizations and the Enduring Role of Religion in Promoting Democratic Engagement. Voluntas: International Journal of Voluntary and Nonprofit Organizations, 29, 1068-1079.

Gallup. (2019). Millennials' Religiosity Amidst the Rise of the Nones. Gallup.Com. https://news.gallup.com/opinion/polling-matters/267920/millennials-religiosity-amidstrise-nones.aspx

Gazley, Beth, Brad R. Fulton, Wesley M. Zebrowski, and David P. King. 2022. "Giving and going: Predictors of U.S. congregational participation in disaster response." Nonprofit Management \& Leadership (forthcoming). 
Ghosh, D., \& Vogt, A. (2012). Outliers: An Evaluation of Methodologies. Joint Statistical Meetings, San Diego, CA.

Goldsmith, S., Eimicke, W., \& Pineda, C. (2006). Faith-Based Organizations Versus Their Secular Counterparts: A Primer for Local Officials. Ash Center for Democratic Governance and Innovation, Harvard Kennedy School.

Hall, P. D. (1992). "Inventing the Nonprofit Sector" and Other Essays on Philanthropy, Voluntarism, and Nonprofit Organizations. JHU Press.

Hall, P. D. (2000). Philanthropy, the Welfare State, and the Transformation of American Public and Private Institutions, 1945-2000 [Working Paper]. Available at SSRN: https://ssrn.com/abstract=262652

Hall, P. D. (2006). A Historical Overview of Philanthropy, Voluntary Associations, and Nonprofit Organizations in the United States, 1600-2000. In W. W. Powell \& R. Steinberg (Eds.), The Nonprofit Sector (pp. 32-65). Yale University Press.

Inclusive America Project, PRRI, \& Lake Institute on Faith \& Giving. (2020). Powering Pluralism: Analyzing the Current Philanthropic Landscape. Aspen Institute. https://www.aspeninstitute.org/programs/justice-and-society-program/poweringpluralism-analyzing-the-current-philanthropic-landscape/

Irie, E., Ammann Howard, K., Sengupta Bhatt, R., \& Orensten, N. (2015). Effective Consulting Partnerships to Philanthropy. The Foundation Review, 7(1), 71-81.

IRS. (2020). Instructions for Form 990 Return of Organization Exempt From Income Tax (2020). Internal Revenue Service. https://www.irs.gov/instructions/i990

Jungclaus, A. E. (2021). True Philanthropy: A Religious History of the Secular Non-Profit Family Foundation [Ph.D. Dissertation]. Columbia University. 
Kennedy, S. S., \& Bielefeld, W. (2002). Government Shekels without Government Shackles? The Administrative Challenges of Charitable Choice. Public Administration Review, 62(1), 4-11.

Lakoff, G., \& Johnson, M. (1980). Metaphors We Live By. University of Chicago Press.

Lampkin, L. M. \& Boris, E. T. (2002). "Nonprofit organization data: What we have and what we need." American Behavioral Scientist 45(10), 1675-1715.

Lim, C., \& MacGregor, C. A. (2012). Religion and Volunteering in Context: Disentangling the Contextual Effects of Religion on Voluntary Behavior. American Sociological Review, 77(5), 747-779.

Lindsay, D. M., \& Wuthnow, R. (2010). Financing Faith: Religion and Strategic Philanthropy. Journal for the Scientific Study of Religion, 49(March), 87-111.

Markofski, W., Fulton, B. R., \& Wood, R. L. (2019). Secular Evangelicals: Faith-Based Organizing and Four Modes of Public Religion. Sociology of Religion, 81(2), 158-184.

Mundey, P., King, D. P., \& Fulton, B. R. (2019). "The economic practices of U.S. congregations: A review of current research and future opportunities." Social Compass 66(3), 400-17.

Osili, U., Zarins, S., \& Han, X. (2021). The Giving Environment: Understanding Pre-Pandemic Trends in Charitable Giving. Indiana University Lilly Family School of Philanthropy.

Ralph, A. K. (2021). But What if They Preach: A Guide for Funding Faith-Inspired Grantees with Boundaries and Integrity. The Aspen Institute.

Ratzinger, J., \& Habermas, J. (2006). Dialectics of Secularization: On Reason and Religion (F. Schuller, Ed.). Ignatius Press.

Ressler, R., Fulton, B. R., \& Paxton, P. (2020). Activity and Identity: Uncovering Multiple Institutional Logics in the Nonprofit Sector. Association for Research on Nonprofit Organizations and Voluntary Action Annual Meeting, virtual. 
Schnable, A. (2015). Religion and Giving for International Aid: Evidence from a Survey of U.S. Church Members. Sociology of Religion, 76(1), 72-94.

Sievers, B. R. (2010). Civil Society, Philanthropy, and the Fate of the Commons. University Press of New England.

Soskis, B. (2020). A History of Associational Life and the Nonprofit Sector in the United States. In W. W. Powell \& P. Bromley (Eds.), The Nonprofit Sector: A Research Handbook (3rd ed., pp. 23-80). Stanford University Press.

Staton Bullard, J. (2021). Co-Founder of Inter-Faith Food Shuttle in Durham, North Carolina (A. K. Ralph, Interviewer; On file with interviewer.) [Personal communication]. Taylor, C. (2009). A Secular Age. Harvard University Press.

Townes, A., Firesheets, E. K., \& Francis, M. (2012). Philanthropy in the Faith Community: Mobilizing Faith-Based Organizations for Substance Use Prevention. The Foundation Review, 4(3), 14-20.

Varo, C. V. (2016). Beyond the Opposites: Philological and Cognitive Aspects of Linguistic Polarization. Philology: An International Journal on the Evolution of Languages, Cultures and Texts, 2, 217-236.

Wear, M. (2021). Philanthropists and politicians: Religion is not a problem to solve, it's a partnership opportunity. Religion News Service. https://religionnews.com/2021/05/03/philanthropists-and-politicians-religion-is-not-aproblem-to-solve-its-a-partnership-opportunity/

Wood, R. L., \& Fulton, B. R. (2015). A Shared Future: Faith-Based Organizing for Racial Equality and Ethical Democracy. University of Chicago Press.

Yeager, D. M. (1990). Focus on the Social Gospel: An Introduction. The Journal of Religious Ethics, 18(1), 3-6. 
Faith-Based Public Foundations

Zunz, O. (2012). Philanthropy in America: A History. Princeton University Press. 
Table 1. Mean values and t-tests results for characteristics of faith-based and secular foundations

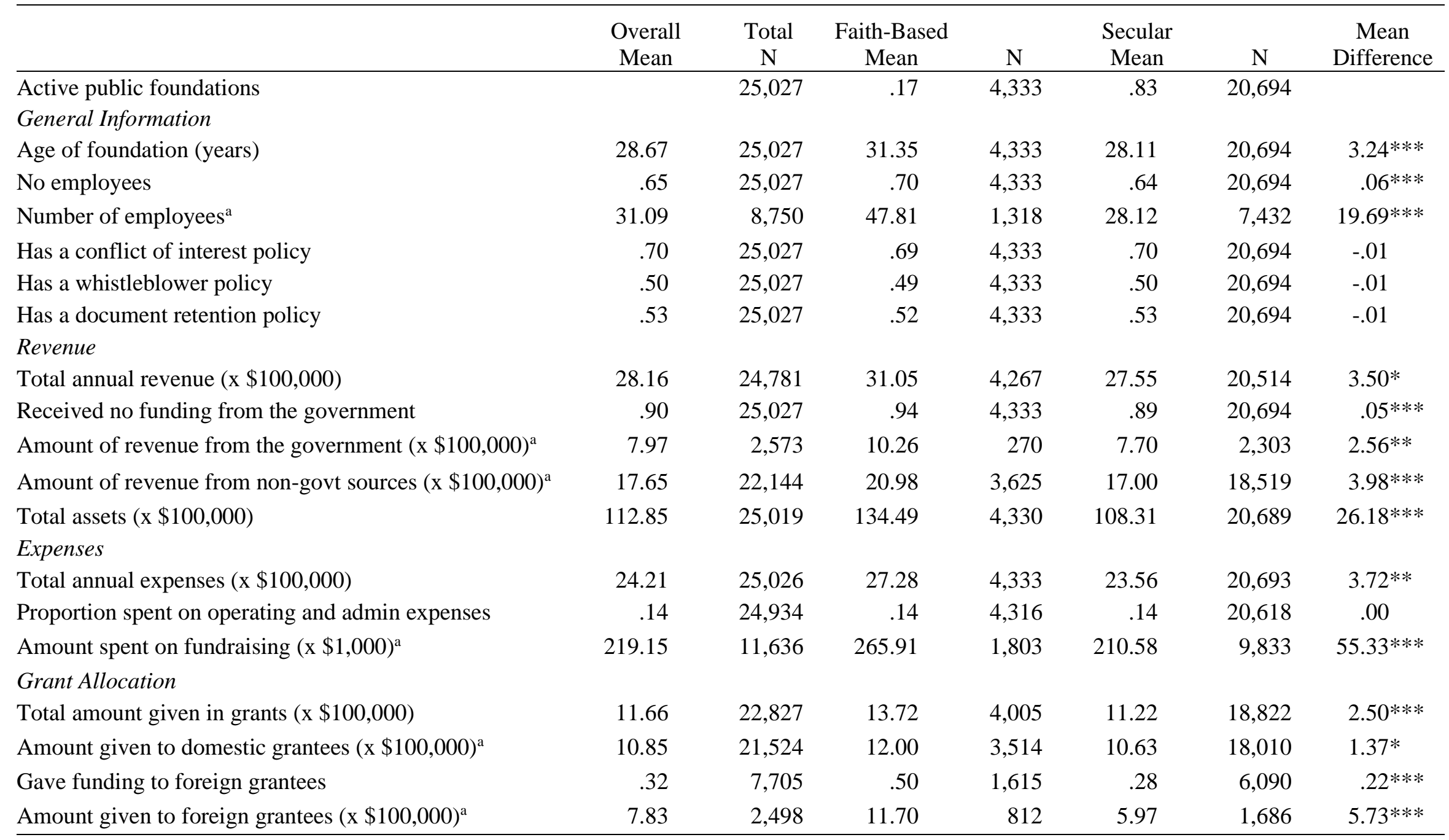

Note: Includes all public foundations that e-filed a Form 990 in 2015 and gave at least one grant in the previous five years.

${ }^{a}$ Among foundations that reported a value greater than 0 for this variable.

$* p<0.05, * * p<0.01, * * * p<0.001$, 